\title{
IMPLEMENTASI PENGELOLAAN DANA DESA DI KAMPUNG MEKURIMA DISTRIK KWAMKI NARAMA KABUPATEN MIMIKA PROVINSI PAPUA
}

\author{
Oleh \\ Rahmat Noviantara Rumbou', \\ Murtir Jeddawi ${ }^{2}$, Udaya Madjid $^{3}$ \\ 1) Badan Kesbangpol Kabupaten Mimika \\ Program Magister Terapan Studi Pemerintahan Daerah Institut Pemerintahan Dalam Negeri \\ viandmeno@gmail.com \\ ${ }^{2,3)}$ Institut Pemerintahan Dalam Negeri
}

\begin{abstract}
This research titled "implementation of managing village grants [dana desa] in Mekurima 1 Village, Kwamki Narama District, Kabupaten Mimika, Papua Province, have a purpose: (1) to analyze implementation of managing village grants [dana desa], (2) to analyze the factors by impact from implementation of managing village grants [dana desa], (3). to identify factor by support, barrier factor and also the solution in implementation of managing village grants [dana desa] in mekurima village, kwamki narama district, Kabupaten Mimika.
\end{abstract}

The model used in this research is the model proposed by George C Edward III that is: (1). Communication, (2) Resources, (3) Disposition (attitudes), (4) bureaucratic structure, in relation to the regulation number 113 of 2014 regarding management of village financial which include 4 basic dimensions are (1) planning, (2) implementation, (3) arrangement, (4) reporting and (5) accountability of management.

This research uses descriptive qualitative method, technique data collection use three ways that is (1) interview, (2) observation, (3) documentation. This research showed: implementation of managing village grants in Mekurima village, Kwamki narama district, that start from planning, implementation, arrangement, reporting, accountability of management, not a whole has demonstrated in accordance with the government regulation number 60 of 2014 regarding village grants originating from state revenue and expenditure budget. affairs regulation number 113 of 2014 regarding management of village financial.

Barrier factor is: (1) communication in relation to the implementation of village grants and lack of transparency in managing village grants, (2) resources in relation to the implementation of village grants is low quality of human resources, (3) disposition (attitudes) in relation to the implementation of village grants is lack of community participation and horizontal conflicts in society, (4) bureaucratic structure in relation to the implementation of village grants is lack of coordination and the dynamic of changing society in mekurima village, kwamki narama district.

Keywords: implementation, managing village grants, local government organization

\section{Abstrak}

Denelitian ini berjudul “Implementasi Pengelolaan Dana desa di Kampung Mekurima, Distrik Kwamki Narama, Kabupaten Mimika, Provinsi Papua", bertujuan: (1) Ingin menganalisis 
implementasi pengelolaan Dana Desa di Kampung Mekurima, Distrik Kwamki Narama, Kabupaten Mimika; (2) Ingin menganalisis faktor-faktor yang memengaruhi implementasi pengelolaan Dana Desa di Kampung Mekurima, Distrik Kwamki Narama, Kabupaten Mimika; serta (3) Ingin mengidentifikasi faktor pendukung dan penghambat serta solusinya dalam implementasi pengelolaan Dana Desa di Kampung Mekurima, Distrik Kwamki Narama, Kabupaten Mimika.

Model yang di gunakan dalam penelitian ini adalah Model George C. Edward III yaitu (1) Komunikasi; (2) Sumber Daya; (3) Disposisi (Sikap Pelaksana); (4) Struktur Birokrasi; dalam hubungannya dengan Peraturan Menteri Dalam Negeri Republik Indonesia No. 113 Tahun 2014 tentang Pengelolaan Keuangan Desa yang di dalamnya memuat 4 dimensi pokok, yaitu (1) Perencanaan; (2) Pelaksanaan; (3) Penatausahaan; (4) Pelaporan; dan (5) Pertanggungjawaban. Penelitian ini menggunakan Metode Penelitian Kualitatif Deskriptif. Adapun Teknik Pengumpulan Data yang digunakan adalah: (1) wawancara; (2) Observasi; dan (3) Dokumentasi.

Hasil penelitian menunjukkan bahwa: Implementasi Pengelolaan Dana Desa di Kampung Mekurima, Distrik Kwamki Narama yang dimulai dari proses perencanaan, pelaksanaan, penatausahaan, pelaporan, dan pertanggungjawaban belum sepenuhnya dapat memenuhi harapan ideal seperti yang diamanatkan dalam Peraturan Pemerintah No. 60 Tahun 2014 tentang Dana Desa yang bersumber dari Anggaran Pendapatan dan Belanja Negara yang secara Implementatif tertuang dalam Peraturan Menteri Dalam Negeri Republik Indonesia No. 113 Tahun 2014 tentang Pengelolaan Keuangan Desa.

Faktor-faktor penghambatyang memengaruhinya adalah: (1) Komunikasi dalam kaitannya dengan implementasi Pengelolaan Dana Desa dan kurang transparansinya pengelolaan Dana Desa; (2) Sumber daya dalam kaitannya dengan implementasi pengelolaan Dana Desa adalah rendahnya kualitas sumber daya manusia; (3) disposisi/sikap pelaksana dalam kaitannya dengan implementasi pengelolaan Dana Desa disebabkan oleh kurangnya partisipasi sekelompok masyarakat dan konflik horizontal di masyarakat; (4) Struktur Birokrasi dalam kaitannya dengan implementasi pengelolaan Dana Desa yang menjadi faktor penghambat adalah lemahnya koordinasi dan dinamika perubahan masyarakat di Kampung Mekurima Distrik Kwamki Narama.

Kata kunci: implementasi, pengelolaan dana desa, organisasi pemerintah kampung

\section{PENDAHULUAN}

$\mathrm{M}$

elihat pentingnya peran Desa dalam mewujudkan pembangunan dan kesejahteraan yang utuh, maka Pemerintah Pusat pada 2014 menetapkan peraturan yang berupa undang-undang yang mengakui adanya "Desa" dengan lahirnya Undang-Undang No. 6 Tahun 2014 tentang Desa. Undangundang ini memberikan hak seluasluasnya pada Desa atau Pemerintah Desa untuk mengatur wilayahnya sendiri serta mengatasi masalahnya sendiri sebagai "Desa” yang otonom.

Dengan lahirnya Undang-Undang No. 6 Tahun 2014 tentang Desa, maka diharapkan ke depan Desa mampu dan berperan aktif untuk menyejahterakan masyarakat, meningkatkan pembangunan desa, serta melaksanakan otonominya sendiri. Guna mencapai hal itu, maka konsekuensinya Pemerintah mengalokasikan anggaran dana di setiap Desa di seluruh Indonesia untuk melaksanakan pembangunan desa. Selanjutnya, untuk pelaksanaan atau implementasi lebih lanjut akan perolehan dana tersebut, maka Pemerintah kemudian menjabarkannya dalam Peraturan Pemerintah No. 60 Tahun 2014 tentang Dana Desa yang bersumber dari Anggaran Pendapatan dan Belanja Negara.

Kemudian sejalan dengan langkah itu, Pemerintah menetapkan pula Peraturan 
Pemerintah No. 43 Tahun 2014 tentang Peraturan Pelaksanaan Undang-Undang No. 6 Tahun 2014 tentang Desa yang kemudian direvisi melalui Peraturan Pemerintah No. 47 Tahun 2015 tentang Perubahan atas Peraturan Pemerintah No. 43 Tahun 2014 tentang Peraturan Pelaksanaan Undang-Undang No. 6 Tahun 2014 tentang Desa. Selanjutnya ditindaklanjuti oleh Menteri Dalam Negeri dengan menetapkan Peraturan Menteri Dalam Negeri Republik Indonesia No. 113 Tahun 2014 tentang Keuangan Desa.

Sejalan dengan kebijakan Pemerintah Pusat, maka Pemerintah Kabupaten Mimika menetapkan rincian dana setiap desa, yaitu dengan dikeluarkannya Peraturan Bupati Kabupaten Mimika No. 3 Tahun 2018 Tanggal 11 Januari 2018 tentang Tata Cara Pembagian dan Penetapan Rincian Dana Desa di setiap kampung. Dalam Peraturan Bupati Mimika tersebut jumlah dana desa yang dialokasikan ke desa dengan melihat keadaan Desa itu sendiri. Untuk Kampung Mekurima sendiri pada 2016 mendapatkan Dana Desa sebesar Rp730.887.000 pada 2017 meningkat menjadi Rp1.028.764.081 sedangkan pada 2018 meningkat lagi menjadi Rp1.188.752.000.

Maka halyang menarikuntukditelitilebih mendalam berkaitan dengan pemanfaatan Dana Desa di Kampung Mekurima, Distrik Kwamki Narama. Kampung Mekurima merupakan Pemerintahan Kampung yang mempunyai keunggulan dalam aspek administrasi Pemerintahan Kampung dibandingkan dengan sembilan kampung lainnya di Distrik Kwamki Narama. Selain itu, sejauh ini dihadapkan dengan berbagai hal yang membutuhkan perhatian pemerintah untuk melakukan perubahan dan penataan manajemen di mana keterbatasan kualitas sumber daya manusia menjadi salah satu kendala dalam merencanakan dan mengelola dana desa.
Berkaitan dengan hal itu, indikasi yang terlihat adalah adanya pengelolaan dana yang belum menjawab substansi permasalahan sebagaimana harapan dan kebutuhan masyarakat yang merujuk pada kondisi objektif terkini. Hal yang demikian berdampak pada sikap masyarakat yang belum sepenuhnya merespons kebijakan pemerintah melalui Dana Desa. Dari inidkasi itulah maka Peneliti juga ingin mendalami berbagai faktor yang menjadi penghambat dalam implementasi pengelolaan Dana Desa di Distrik Kwamki Narama, khususnya pada Kampung Mekurima. Selain itu, hal yang juga menarik perhatian Peneliti untuk melakukan penelitian di Distrik Kwamki Narama dikarenakan daerah ini merupakan daerah rawan konflik horizontal antarkubu yang sering disebut, "Kubu Atas" dan "Kubu Bawah".

\section{Perumusan Masalah}

Berdasarkan latar belakang masalah di atas, maka dalam penelitian ini dapat dirumuskan masalah yang akan diteliti adalah sebagai berikut.

1. Bagaimana Pengelolaan Dana Desa di Kampung Mekurima, Distrik Kwamki Narama, Kabupaten Mimika, Provinsi Papua?

2. Faktor-faktorapasajayangteridentifikasi sebagai faktor pendukung dan faktor penghambat serta bagaimana solusinya dalam implementasi pengelolaan Dana Desa di Kampung Mekurima, Distrik Kwamki Narama, Kabupaten Mimika, Provinsi Papua?

\section{KAJIAN PUSTAKA}

Kajian pustaka dalam penelitian ini. Penelti akan mencoba menguraikan dan meninjau dari Perspektif Teoretis tentang: (1) Konsep Implementasi; (2) Konsep Pengelolaan; (3) Konsep Desa; dan (4) Konsep Pengelolaan Dana Desa. 


\section{Implementasi Kebijakan}

Implementasi kebijakan merupakan suatu tahap dan tidak terpisahkan dari keseluruhan proses kebijakan. Dunn ${ }^{1}$ menjelaskan bahwa "Kebijakan yang telah diambil dilaksanakan oleh unit-unit administrasi yang memobilisasikan sumber daya finansial dan manusia". Implementasi kebijakan merupakan aspek penting dari keseluruhan proses pembuatan kebijakan, karena implementasi merupakan aktivitas dalam mencapai tujuan yang telah ditetapkan. Implementasi kebijakan yang berhasil menjadi faktor penting dalam keseluruhan proses kebijakan. Dengan pendapat tersebut, para ahli administrasi publik juga sependapat mengenai pentingnya peranan pembuatan kebijakan dan implementasi kebijakan sebagai suatu mata rantai proses kebijakan, seperti dikemukakan Edward III dalam Elsye $^{2}$ mengatakan empat faktor utama yang dominan memengaruhi implementasi kebijakan adalah Communication (Komunikasi), Resources (Sumber Daya), Disposition (Disposisi dan Bureaucratic Structure (Struktur Birokrasi). Selanjutnya akan diuraikan keempat faktor yang memengaruhi kebijakan dimaksud, yaitu

1. Komunikasi Kebijakan

2. Sumber daya Kebijakan

3. Disposisi/sikap pada kebijakan

4. Struktur kebijakan

Menurut Edward III dalam Widodo ${ }^{3}$, masalahutamaadministrasi publikadalahlack of attention to implementation. Dikatakannya:

1 Dunn, William N. 2003. Pengantar Analisis Kebijakan Publik. Edisi Kedua Terjemahnya Samodra Wibawa, Diah Asitadani, Agus Heruanto Hadna, dan Erwan Agus, Hal 24

2 Elsye Rosmery. 2013 Desentralisasi Fiskal.Alqaprint Jatinangor, Hal 6

3 Widodo, Joko, 2001, Good Governance, Sidorajo, Penerbit Insan Cendekia, hal. 195 "without effective implementation the decision of police makers will not be corried out successfully" (tanpa implementasi efektif, keputusan dari pembuat kebijaksanaan tidak akan diselesaikan dengan sukses). Selanjutnya menurut Edward III, implementasi kebijakan dipengaruhi oleh empat hal yang yang selanjutnya dapat dideskripsikan, sebagai berikut.

\section{Komunikasi (Communucation)}

Komunikasi merupakan sarana untuk menyebarluaskan informasi. Apa yang menjadi tujuan dan sasaran kebijakan harus ditransmisikan kepada kelompok sasaran sehingga akan mengurangi distorsi implementasi.

\section{Sumber Daya (Ressources)}

Sumber daya dimaksud dapat berupa Sumber Daya Manusia dan Sumber Daya Finansial.

\section{Sikap Pelaksana (Dispotition of} Attitude)

Berkaitan dengan bagaimana sikap implementor dalam suatu implementasi kebijakan.

\section{Struktur Birokrasi (Bureaucratic} Structure)

Suatu kebijakan sering kali melibatkan beberapa lembaga atau organisasi dalam proses implementasinya, sehingga diperlukan koordinasi yang efektif antarlembaga-lembaga terkait dalam mendukung keberhasilan implementasi.

\section{Pengelolaan}

Wardoyo $^{4}$ memberikan definisi: "Pengelolaan adalah suatu rangkaian kegiatan yang berintikan perencanaan, pengorganisasian penggerakan dan pengawasan dalam mencapai tujuan yang telah ditetapkan sebelumnya".

4 Wardoyo.(1980) . Kamus Besar Bahasa Indonesia. Jakarta: Balai Pustaka, Hal 41 
Menurut Harsoyo ${ }^{5}$ "Pengelolaan adalah suatu istilah yang berasal dari kata "Kelola" mengandung arti serangkaian usaha yang bertujuan untuk menggali dan memanfaatkan segala potensi yang dimiliki secara efektif dan efisien guna mencapai tujuan tertentu yang telah direncanakan sebelumnya".

Bertolak dari definisi di atas, maka dapatlah disimpulkan bahwa "Pengelolaan adalah suatu rangkaian kegiatan yang berintikan perencanaan, pengorganisasian, penggerakan dan pengawasan yang bertujuan menggali dan memanfaatkan Sumber Daya Alam (SDA) dan Sumber Daya Manusia (SDM) yang dimiliki secara efektif untuk mencapai tujuan organisasi yang telah ditentukan".

Berdasarkan definisi manajemen di atas secara garis besar tahap-tahap dalam melakukan manajemen meliputi melakukan perencanaan, pengorganisasian, pelaksanaan, dan pengawasan. Perencanaan merupakan proses dasar dari suatu kegiatan pengelolaan dan merupakan syarat mutlak dalam suatu kegiatan pengelolaan. Kemudian pengorganisasian berkaitan dengan pelaksanaan perencanaan yang telah ditetapkan. Sementara itu pengarahan diperlukan agar menghasilkan sesuatu yang diharapkan dan pengawasan yang dekat. Dengan evaluasi, dapat menjadi proses monitoring aktivitas untuk menentukan apakah individu atau kelompok memperoleh dan mempergunakan sumber-sumbernya secara efektif dan efisien untuk mencapai tujuan.

Berdasarkan fungsi manajemen (pengelolaan) di atas secara garis besar dapat disampaikan bahwa tahap-tahap dalam melakukan manajemen meliputi:

5 Harsoyo. 1977. Pengertian Pengelolaan. http: //id.shvoong.com/writing-and speaking/ presenting/2108155-pengertian-pengelolaan/. Diakses pada tanggal 18 November 2018, Hal 121.
(1) perencanaan; (2) pengorganisasian; (3) pelaksanaan; dan (4) pengawasan. Fungsifungsi manajemen itu bersifat universal, di mana saja dan dalam organisasi apa saja. Namun, semuanya tergantung pada tipe organisasi, kebudayaan dan anggotanya.

Dalam penelitian ini, Peneliti berpedoman pada Peraturan Menteri Dalam Negeri Nomor: 113 Tahun 2014 tentang Pengelolaan Keuangan Desa. Pengelolaan ${ }^{6}$ mengandung empat dimensi, yaitu (1) Perencanaan; (2) Pelaksanaan; (3) Penatausahaan; (4) Pelaporan; dan (5) Pertanggungjawaban.

\section{Desa}

Secara umum, disahkannya UndangUndang No. 6 Tahun 2014 tentang Desa (selanjutnya disebut Undang-Undang Desa) mendapatkan sambutan baik dari masyarakat. Banyak pihak menilai bahwa Undang-Undang Desa tersebut dapat menjadi jawaban bagi kebutuhan masyarakat desa.

Desa adalah Desa dan Desa Adat atau yang disebut dengan nama lain, selanjutnya disebut Desa, adalah kesatuan masyarakat hukum yang memiliki batas wilayah yang berwenang untuk mengatur dan mengurus urusan pemerintahan, kepentingan masyarakat setempat berdasarkan prakarsa masyarakat, hak asal usul, dan atau hak tradisional yang diakui dan dihormati dalam sistem pemerintahan Negara Kesatuan Republik Indonesia. ${ }^{7}$ Istilah "Desa" hanya dikenal di Jawa, sedangkan di luar Jawa misalnya di Sumatera, Kalimantan dan Sulawesi, sebutan untuk wilayah dengan pengertian serupa "Desa" sangat beraneka ragam, sesuai dengan asal mula terbentuknya area "Desa" tersebut, baik berdasarkan pada prinsip-prinsip ikatan genealogis, atau ikatan

6 Permendagri No. 113 tentang Pengelolaan Keuangan Desa, Pasal 20-43.

7 Undang-undang Republik Indonesia No. 6 Tahun 2014 tentang Desa Pasal 1 ayat 1 
teritorial, dan bahkan berdasarkan tujuan fungsional tertentu (semisal Desa Petani atau Desa Nelayan, atau Desa Penambang Emas) dan sebagainya.

Definisi secara sosiologis, Desa merupakan sebuah gambaran dan kesatuan masyarakat/komunitas penduduk yang bertempat tinggal dalam lingkungan di mana mereka saling mengenal dengan baik dan arah kehidupan mereka relatif homogen serta banyak bergantung pada alam. Komunitas di atas kemudian berkembang menjadi satu kesatuan masyarakat hukum di mana kepentingan bersama penduduk diatur menurut hukum adat yang dilindungi dan dilambangkan. Ciri dari masyarakat hukum adat yang otonomi adalah yang berhak mempunyai wilayah sendiri dengan batas yang sah, berhak mengangkat bupati daerahnya/majelis sendiri berhak mempunyai sumber keuangan sendiri, serta berhak atas tanahnya sendiri.

Daerah Kabupaten/Kota sesuai dengan ketentuan peraturan perundang-undangan. Otonomi Desa merupakan hak, wewenang dan kewajiban untuk mengatur dan mengurus sendiri urusan pemerintahan dan kepentingan masyarakat berdasarkan hak asal-usul dan nilai-nilai sosial budaya yang ada pada masyarakat untuk tumbuh dan berkembang mengikuti perkembangan desa tersebut. Urusan pemerintahan berdasarkan asal-usul desa, urusan yang menjadi wewenang pemerintahan kabupaten/kota diserahkan pengaturannya kepada desa. Namun harus selalu diingat bahwa tidak ada hak tanpa kewajiban dan tidak ada kewenangan tanpa tanggung jawab. Oleh karena itu, dalam pelaksanaan hak, kewenangan dan kebebasan dalam penyelenggaraan Otonomi Desa harus tetap menjunjung nilai-nilai tanggung jawab terhadap Negara Kesatuan Republik Indonesia dengan menekankan bahwa Desa adalah bagian yang tidak terpisahkan dari bangsa dan negara Indonesia. Pelaksanaan hak, wewenang dan kebebasan Otonomi
Desa menuntut tanggung jawab untuk memelihara integritas, persatuan dan kesatuan bangsa dalam ikatan Negara Kesatuan Republik Indonesia dan tanggung jawab untuk mewujudkan kesejahteraan rakyat yang dilaksanakan dalam koridor Peraturan Perundang-undangan yang berlaku.

Adapun kewenangan Desa ${ }^{8}$ meliputi kewenangan di bidang Penyelenggaraan Pemerintahan Desa, Pelaksanaan Pembangunan Desa, Pembinaan Kemasyarakatan Desa dan Pemberdayaan Masyarakat Desa berdasarkan prakarsa masyarakat, hak asalusul, dan adat istiadat Desa.

\section{Pengelolaan Dana Desa}

Berdasarkan Peraturan Pemerintah No. 60 Tahun 2014, Dana Desa adalah "Dana yang bersumber dari APBN yang diperuntukkan bagi Desa yang ditransfer melalui Anggaran Pendapatan Belanja Daerah (APBD) Kabupaten/Kota dan digunakan untuk membiayai penyelenggaraan pemerintahan, pelaksanaan pembangunan, pembinaan kemasyarakatan dan pemberdayaan masyarakat". Sekretaris Desa menyusun Rancangan Peraturan Desa tentang Anggaran Pendapatan dan Belanja Desa (APBDes) berdasarkan Rencana Pembangunan Jangka Menengah Desa (RPJMDes) lima tahunan, lalu menyusun Rencana Kerja Pemerintah Desa (RKPDes) tahun berkenaan kemudian menyampaikan Rancangan Peraturan Desa tentang APBDes tersebut kepada Kepala Desa. Kemudian Kepala Desa menyampaikan Rancangan Peraturan Desa tentang APBDes tersebut kepada Badan Permusyawaratan Desa (BPD) untuk dibahas dan disepakati bersama paling lambat pada Oktober tahun berjalan ${ }^{9}$.

8 Pasal 18 Undang-Undang No. 6 Tahun 2014 tentang Desa

9 Peraturan Menteri Dalam Negeri Republik Indonesia No. 113 Tahun 2014 
Dana Desa merupakan transfer dana langsung anggaran belanja Pemerintah yang ditetapkan dalam Anggaran Pendapatan dan Belanja Negara (APBN) yang disalurkan oleh Kabupaten/Kota yang dilakukan dengan cara pemindahbukuan dari Rekening Kas Umum Negara (RKUN) ke Rekening Kas Umum Daerah (RKUD), lalu Kabupaten/Kota menyalurkan Dana Desa tersebut kepada Desa dengan cara pemindahbukuan dari Rekening Kas Umum Daerah (RKUD) ke Rekening Kas Desa ${ }^{10}$. Dana Desa diprioritaskan untuk membiayai Belanja Pembangunan dan Pemberdayaan Masyarakat. Penggunaan Dana Desa tertuang dalam prioritas Belanja Desa yang disepakati dalam Musyawarah Desa.

Dana Desa digunakan untuk membiayai pembangunan Desa yang ditujukan untuk meningkatkan kesejahteraan masyarakat Desa, peningkatan kualitas hidup manusia serta penanggulangan kemiskinan dengan prioritas penggunaan Dana Desa diarahkan untuk pelaksanaan program dan kegiatan Pembangunan Desa, Desa dalam perencanaan program dan kegiatan pembangunan Desa yang dibiayai Dana Desa, dapat mempertimbangkan tipologi Desa berdasarkan tingkat perkembangan kemajuan Desa.

Dana Desa digunakan untuk membiayai program dan kegiatan bidang Pemberdayaan Masyarakat Desa yang ditujukan untuk meningkatkan kapasitas dan kapabilitas masyarakat Desa dengan mendayagunakan potensi dan sumber dayanya sendiri sehingga Desa dapat menghidupi dirinya secara mandiri. Pengembangan kapasitas di Desa diswakelola oleh Desa atau badan kerja sama antardesa. Swakelola oleh badan kerja sama antardesa dilaksanakan berdasarkan ketentuan dan mekanisme kerja sama

10 Pasal 15 Peraturan Pemerintah No 60 Tahun 2014 tentang Dana Desa yang bersumber dari Anggaran Pendapatan dan Belanja Negara. antardesa $^{11}$. Desa dalam perencanaan program dan kegiatan pemberdayaan masyarakat Desa yang dibiayai Dana Desa, dapat mempertimbangkan tipologi Desa berdasarkan tingkat perkembangan kemajuan Desa.

\section{METODE PENELITIAN}

Metode penelitian yang digunakan penulis dalam penelitian ini adalah metode penelitian kualitatif dengan pendekatan deskriptif. Peneliti menyimpulkan bahwa metode penelitian kualitatif adalah metode penelitian yang menjajaki atau menggali sesuatu hal/masalah secara mendalam dan komprehensif dari kumpulan informasi dengan membaca kejadian atau fenomena di sekitarnya untuk membantu menjelaskan dan menggambarkan permasalahan yang diteliti. Sejalan dengan hal tersebut, maka penelitian ini mengambil fokus pengamatan pada Kampung Mekurima, Distrik Kwamki Narama, Kabupaten Mimika. Seperti yang telah ditegaskan di atas, penelitian ini merupakan Penelitian Deskriptif Kualitatif untuk mendalami dan menjajaki serta menjelaskan Implementasi Pengelolaan Dana Desa yang telah dilaksanakan. Sumber data yang digunakan dalam penelitian ini terdiri dari person, paper dan place.

1. Sumber data person dalam hal ini adalah Kepala yang diwakili oleh Sekretaris Dinas Pemberdayaan Masyarakat dan Kampung, Kepala yang diwakili Sekretaris Distrik Kwamki Narama, Kepala Kampung Mekurima dan jajarannya, Kepala Badan Musyawarah Kampung Mekurima, Pendamping Dana Desa Kampung Mekurima, serta tokoh-tokoh masyarakat/perempuan Kampung Mekurima.

11 Pasal 7 ayat (30) dan (4) Peraturan Menteri Desa, Pembangunan Daerah Tertinggal, dan Transmigrasi No. 19 Tahun 2017 tentang Penetapan Prioritas Penggunaan Dana Desa Tahun 2018 


\section{Sumber data Paper}

Sumber data dalam penelitian ini sumber data yang diambil berupa peraturan perundang-undangan, peraturan daerah, peraturan bupati, dokumen-dokumen perencanaan dan penganggaran, dokumen pelaksanaan, dokumen pelaporan dan pertanggungjawaban dan sumber tertulis lainnya yang berkaitan dengan pelaksanaan dana desa di lokus penelitian.

3. Sumber data Place

Tempat yang menjadi lokus observasi dalam penelitian ini adalah Kampung Mekurima yang berada di Distrik Kwamki Narama, Kabupaten Mimika, Provinsi Papua. Selain itu, peneliti juga akan mengambil data penelitian di instansi terkait yaitu Dinas Pemberdayaan Masyarakat Kampung.

\section{HASIL PENELITIAN}

Hasil penelitian dan pembahasan merupakan hasil pengumpulan data tentang objek penelitian yang dilakukan oleh Peneliti di lokus penelitian yang berisikan data dan fakta yang ada mengenai pelaksanaan Dana Desa dalam mewujudkan pembangunan dan pemberdayaan masyarakat di Kampung Mekurima, Distrik Kwamki Narama, Kabupaten Mimika, Provinsi Papua sebagaimana Untuk selanjutnya akan diuraikan sebagai berikut.

\section{Pengelolaan Dana Desa di Kampung Mekurima, Distrik Kwamki Narama, Kabupaten Mimika, Provinsi Papua Tahun 2018}

Salah satu tujuan dari penelitian ini adalah untuk menganalisis Pengelolaan Dana Desa di Kampung Mekurima, Distrik Kwamki Narama, Kabupaten Mimika, Provinsi Papua Tahun 2018. Adapun tahapan yang ingin dideskripsikan dalam penelitian ini adalah dimulai dari:
(1) Proses Perencanaan Anggaran Dana Desa;

(2) Pelaksanaan Program Dana Desa;

(3) Penatausahaan Program Dana Desa;

(4) Pelaporan Program Dana Desa; dan

(5) Pertanggungjawaban Program Dana Desa.

Berdasarkan hasil wawancara dengan beberapa informan, penulis mengambil simpulan bahwa pengelolaan dana desa di Kampung Mekurima adalah sebagai berikut.

\section{- Proses Perencanaan}

Komunikasi dan kemampuan Sumber Daya Manusia sangat penting dalam memberikan pemahaman kepada warga masyarakat terkait dengan Program Pemerintah khususnya yang digulirkan melalui Program Dana Desa di Kampung Mekurima, Distrik Kwamki Narama, Kabupaten Mimika. Belum semua masyarakat memahami dengan baik dan utuh Skala Prioritas Program Dana Desa yang digulirkan oleh Pemerintah sejak 2015 yang lalu.

Meskipun telah disepakati dalam Musyawarah Perencanaan Pembangunan Kampung, namun masih ditemukan fakta juga bahwa belum semua usulan itu merupakan aspirasi masyarakat setempat karena ada di antara masyarakat yang tidak merasa dilibatkan dalam proses perencanaan Program Dana Desa

\section{- Proses Pelaksanaan}

Pelaksana Kegiatan telah diarahkan oleh Kepala Kampung dalam pelaksanaan Pembangunan Jalan Desa di Kampung Mekurima. Hal yang perlu menjadi perhatian ke depan adalah perlu adanya fasilitas kegiatan pelatihan keterampilan bagi masyarakatsehingga dapat mendayagunakan potensi Sumber Daya Manusia di kampung untuk lebih mandiri dalam pengelolaan Dana Desa. Pelaksana Kegiatan telah diarahkan 
oleh Kepala Kampung dalam melaksanakan Pembangunan dan Pengelolaan Instalasi Lampu Penerangan Jalan di Kampung Mekurima. Hal ini sangat dirasakan manfaatnya oleh masyarakat kampung. Pelaksana Kegiatan telah diarahkan oleh Kepala Kampung dalam melaksanakan Kegiatan Peningkatan Kapasitas Lembaga Masyarakat di Kampung Mekurima. Hal ini sangat dirasakan manfaatnya karena berkaitan dengan pembinaan keagamaan masyarakat di kampung yang berpotensi rawan konflik. Pelaksana Kegiatan telah diarahkan oleh Kepala Kampung dalam melaksanakan Kegiatan Pengadaan Bibit Tanaman Pertanian dan Perkebunan. Dari sisi output kegiatan sesungguhnya telah tercapai. Namun, dari sisi inpact dan benefit masih perlu dievaluasi sehingga ke depan perlu adanya sinergitas dan keterpaduan dalam pelaksanaan kegiatan di Kampung Mekurima.

\section{- Proses Penatausahaan}

Penatausahaan dilakukan oleh Bendahara Desa/Kampung. Dengan demikian Bendahara Desa wajib melakukan pencatatan setiap penerimaan dan pengeluaran serta melakukan tutup buku setiap akhir bulan secara tertib. Konsekuensinya, Bendahara Desa/Kampung wajib mempertanggungjawabkan uang melalui laporan pertanggungjawaban. Laporan pertanggungjawaban disampaikan setiap bulan kepada Kepala Kampung paling lambat tanggal sepuluh - bulan berikutnya.

Terdapat tiga hal pokok dalam kaitannya dengan Penatausahaan Program Dana Desa, yaitu (1) Buku Kas Umum; (2) Buku Pembantu Pajak; dan (3) Buku Bank.

Berdasarkan uraian hasil investigasi dan wawancara yang telah terangkum di atas maka Peneliti merangkum hasil penelitian yang berkaitan dengan Penatausahaan Program Dana Desa, dapat disimpulkan bahwa: a. Dalam pengelolaan Dana Desa, Bendahara Kampung belum dibekali dengan administrasi pembukuan Buku Kas Umum.

b. Dalam pengelola Dana Desa, Bendahara Kampung belum dibekali dengan administrasi pembukuan Buku Pembantu Pajak yang pembukuannya dilakukan secara manual.

c. Demikian halnya dengan Buku Bank, Bendahara Kampung belum dibekali dengan Administrasi Pembukuan.

\section{- Pelaporan}

Dalam kaitan ini Kepala Kampung menyampaikanlaporan realisasi pelaksanaan APBDes/Kampung kepada Bupati, berupa Laporan Semester Pertama dan Laporan Semester. Merujuk pada aturan perundangundangan yang dijadikan rujukan utama dalam pengelolaan Dana Desa, maka sangat jelas bahwa untuk tertibnya administrasi maka Pengelolaan Dana Desa wajib menyiapkan dua bentuk Pelaporan, yaitu (1) Pelaporan Berkala; dan (2) Pelaporan Akhir.

Adapun Laporan Berkala, menurut ketentuan dibuat dalam dua tahap, yaitu, Laporan Semester Pertama (paling lambat pada Juli). Laporan Semester Akhir Tahun (paling lambat pada Januari)

Pelaporan Akhir merupakan rangkuman dari keseluruhan laporan selam tahun berjalan. Berdasarkan hasil observasi langsung pada lokus penelitian, ternyata hingga saat penelitian dilakukan, pelaporan akhir masih dalam proses penyusunan/ penyelesaian.

Peneliti merangkum hasil penelitian yang berkaitan dengan Pelaporan Program Dana Desa, dapat disimpulkan bahwa:

a. Masih diketemukan keterlambatan dalam penyampaian Pelaporan Berkala dan Pelaporan Akhir Program Dana Desa; 
b. Adapun yang menjadi kendala dalam keterlambatan penyerahan penyerahan bukti Pelaporan Berkala dan Pelaporan Akhir;

c. Selain itu, kendala lain yang juga menjadi salah satu faktor pemicu adalah situasi konflik horizontal yang membuat ketidaknyamanan Aparat Kampung dalam menjalankan tugasnya.

d. Keterbatasan pengetahuan dalam penguasaan teknologi informasi dan perangkat komputer menjadi salah satu kendala ketergantungan pada situasi konflik.

\section{- Pertanggungjawaban}

Proses pertanggungjawaban terbagi menjadi dua, yaitu (1) Laporan Realisasi Pelaksanaan Dana Desa, (2) Evaluasi Pelaksanaan. Sejauh kegiatan penelitian berlangsung memang ada di antara Aparat Kampung yang tidak aktif menjalankan tugasnya sehingga kantor terlihat sepi dan tidak ada aktivitas. Hal ini juga merupakan salah satu kendala yang harus dicarikan solusinya sehingga ke depan pelayanan kepada masyarakat benar-benar dapat dilakukan dengan baik. Di sisi lain, citra pemerintah di mata masyarakat juga menjadi baik Jika hal itu dapat diperbaiki maka secara kuantitatif dan kualitatif masyarakat akan meresponsnya dengan positif pula.

Berdasarkan uraian hasil investigasi dan wawancara yang telah terangkum di atas maka peneliti merangkum hasil penelitian yang berkaitan dengan pertanggungjawaban program dana desa, dapat disimpulkan bahwa:

a. Sampai dengan kegiatan penelitian yang dilakukan oleh Peneliti, ditemukan fakta bahwa proses Pelaporan Pertanggungjawaban Program Dana Desa Tahun Anggaran 2018 masih dalam tahap penyelesaian;

b. Adapun yang menjadi kendala dalam keterlambatan penyerahan penyerahan bukti akhir pertanggungjawaban kegiatan;

c. Selain itu, kendala lain yang juga menjadi salah satu faktor pemicu adalah terbatasnya pengetahuan dan keterampilan di bidang teknologi informasi dan perangkat komputer.

d. Hal ini menjadi salah satu faktor pemicu keterlambatan pada situasi konflik horizontal yang membuat ketidaknyamanan aparat kampung dalam menjalankan tugasnya.

Identifikasi Faktor Pendukung dan Penghambat serta Solusi terhadap Implementasi Pengelolaan Dana Desa di Kampung Mekurima

\section{- Faktor Pendukung}

a. Komunikasi:

- $\quad$ Ketersediaan Informasi.

- Sosialisasi Dana Desa.

b. Sumber Daya:

- Kepemimpinan

- Kemampuan pengelola dana desa.

- Partisipasi masyarakat.

c. Disposisi/Sikap Pelaksana

- Persepsi pelaksana dalam pengelolaan dana desa.

- Respons pelaksana dalam pengelolaan dana desa.

- Tindakan pelaksana dalam pengelolaan dana desa.

d. Struktur Birokrasi

- Otoritas pemerintah

- Otoritas hukum

- Terbentuknya struktur organisasi

\section{- Faktor Penghambat}

a. Komunikasi

- $\quad$ Lingkup sosialisasi dana desa.

- Kurangnya transparansi pengelolaan dana desa. 
b. Sumber daya

- Rendahnya kualitas SDM.

c. Disposisi/Sikap Pelaksana

- Kurangnya partisipasi masyarakat.

- Konflik horizontal di masyarakat.

d. Struktur birokrasi

- Lemahnya koordinasi.

- Dinamika perubahan masyarakat.

- Solusi terhadap Faktor Penghambat

a. Komunikasi

- Meningkatkan Sosialisasi kepada masyarakat terkait Kebijakan Pengelolaan Dana Desa.

- Meningkatkan Pemahaman masyarakat mengenai Dana Desa.

- Membangun Partisipasi Masyarakat dalam Pelaksanaan dan Pengawasan Kegiatan

- Menyosialisasikan Pengetahuan melalui Teknologi Informasi

b. Sumber daya

- Meningkatkan Pendidikan Pelaksana Pengelolaan Dana Desa.

- Meningkatkan Pengetahuan dan Pemahaman Pelaksana terhadap Pengelolaan Dana Desa.

- Meningkatkan Keterampilan Sumber Daya Manusia.

c. Disposisi/Sikap pelaksana

- Meningkatkan Pemahaman Para Pelaksana Program.

- Memberikan Pemahaman yang benar terhadap pengelolaan Program Dana Desa.

d. Struktur Birokrasi

- Menata pembagian tugas.

- Meningkatkan koordinasi tim pelaksana.

\section{SIMPULAN DAN SARAN}

\section{SIMPULAN}

Pertama, Pengelolaan dana desa di Kampung Mekurima sudah berjalan baik namun perlu ditingkatkan lagi.

\section{a. Aspek perencanaan}

Sudah sesuai dalam menjalankan aspirasi masyarakat dengan menyelesaikan semua permintaanpermintaan masyarakat

b. Aspek Pelaksanaan

Pembagian tugas Aparat Kampung belum merata dan belum sepenuhnya sesuai dengan Tugas Pokok dan Fungsi Aparat Kempung yang bersangkutan.

Meskipun demikian dapat dimaklumi, sebab Kepala Kampung Mekurima memiliki pertimbangan tersendiri dalam mendistribusikan tugas kepada Aparat Kampung, Salah satu pertimbangannya adalah berkaitan dengan Disiplin dan Motivasi Aparat.

\section{c. Aspek Penatausahaan}

Masih ditemukan fakta yang kemudian dapat disimpulkan Belum optimalnya peran Bendahara Desa dalam menata administrasi pembukuan sebagai mana yang dipersyaratkan, seperti: Buku Kas Umum, Buku Bank dan Buku Pajak dan Belum ditatanya administrasi surat menyurat termasuk sistem pengarsipannya.

\section{d. Aspek Pelaporan}

Dalam proses pelaksanaan Pelaporan Realisasi Penggunaan Dana Desa belum sesuai dengan jadwal yang telah ditetapkan sehingga berdampak pada keterlambatan untuk pencairan dan pada berikutnya.

\section{e. Aspek Pertanggungjawaban}

Proses penyampaian Pelaporan Akhir Pertanggungjawaban Dana Desa juga masih mengalami keterlambatan. 
Kedua, identifikasi faktor pendukung dan faktor penghambat serta solusinya.

\section{a. Komunikasi}

Faktor Pendukung:

- Ketersediaan informasi terkait dengan pengelolaan dana desa yang secara rutin diberikan oleh Dinas Pemberdayaan Masyarakat Kampung Kabupaten Mimika

- Sosialisasi dana desa yang sejauh ini dilakukan kegiatannya oleh Dinas Pemberdayaan Masyarakat Kampung Kabupaten Mimika.

Faktor Penghambat:

- Lingkup sosialisasi dana desa yang sejauh ini masih terbatas pada jajaran aparat Kampung dan Bamuskam

- Sosialisasi khusus pada masyarakatbelum pernah dilakukan

- Kurangnya transparansi pengelolaan dana desa.

Solusi:

- Meningkatkan sosialisasi langsung kepada masyarakat terkait kebijakan pengelolaan dana desa serta meningkatkan pemahaman masyarakat mengenai dana desa denganmengintensifkankomunikasi serta membangun partisipasi masyarakat dalam pelaksanaan dan pengawasan kegiatan dengan membangun pendekatan sosiologis dan antropologi budaya.

\section{b. Sumber daya}

Faktor Pendukung:

- Kepemimpinan Kepala Kampung yang mampu mengayomi dan memberdayakan masyarakat.

- Kemampuan pengelola dana desa yang dibangun melalui pola pendekatan sosiologis.

- Partisipasi masyarakat yang dilakukan secara psikologis personel dan sosiologi budaya.

Faktor Penghambat:

- Rendahnya kualitas sumber daya manusia.

Solusi:

- Meningkatkan pendidikan bagi pengelolaan dana desa, baik pendidikan formal melalui program paket dan keterampilan teknis dan meningkatkan pengetahuan dan pemahaman pelaksana terhadap pengelolaan dana desa di mana keterampilan teknis di bidang pertanian, perkebunan, peternakan, kerajinan dan keterampilan lainnya dalam menunjang administrasi perkantoran bagi aparat kampung.

c. Disposisi/Sikap Pelaksana

Faktor Pendukung:

- Adanya persepsi pelaksana yang mendukung kebijakan

- Kesungguhan kepala kampung dalam pengelolaan dana desa.

- Kesesuaian pengelolaan dana desa dengan kebijakan pengelolaan dana desa

Faktor Penghambat;

- Kurangnya partisipasi masyarakat dalam proses pengambilan keputusan pada saat penyusunan program

- Konflik horizontal yang kemudian memicu perang suku yang terjadi di masyarakat Kwamki Narama.

Solusi:

- Meningkatkan pemahaman para pelaksana program dan desa dan memberikan pemahaman yang benar terhadap program dana desa.

\section{d. Struktur birokrasi}

Faktor pendukung:

- Otoritas pemerintah dalam menyediakan dana desa di Kabupaten Mimika 
- Adanya otoritas hukum dalam implementasi pengelolaan dana desa dan adanya aturan pelaksanaannya sebagai rujukan bagi aparat pelaksana.

- Terbentuknya struktur organisasi pendukung dalam implementasi pengelolaan dana desa.

Faktor penghambat:

- Lemahnya koordinasi antarlini pemerintahan

- Dinamika perubahan masyarakat yang cenderung jalan di tempat.

Solusi:

- Menata pembagian tugas bagi pengelola dana desa dan meningkatkan koordinasi tim pelaksana dana desa.

\section{SARAN}

Berdasarkan simpulan dari hasil penelitian ini, maka untuk memperbaiki Pengelolaan Dana Desa di Kampung Mekurima, disarankan:

Pertama, berkaitan dengan Pengelolaan Dana Desa Perlu dilakukan pembinaan dan sosialisasi yang terstruktur dan sistematis sesuai Permendagri No. 113 Tahun 2014 yang berproses dimulai dari: (1) Perencanaan; (2) Pelaksanaan; (3) Penatausahaan; (4) Pelaporan; dan (5) Pertanggungjawaban.

Kedua, berkaitan dengan faktorfaktor yang memengaruhi implementasi pengelolaan dana desa di Kampung Mekurima

a. Komunikasi:

1) Perlu dilakukan intensitas dalam membangun komunikasi berkaitan dengan Implementasi Pengelolaan Dana Desa;

2) Perlunya kejelasan program yang diarahkan untuk masyarakat sehingga kepastiannya jelas dan tidak mengambang;
3) Perlukonsistensi dalam menetapkan program sehingga masyarakat dipuaskan.

b. Sumber Daya:

1) Perlu mempersiapkan kualitas Sumber Daya Aparatur melalui pendidikan formal dan informal;

2) Perlu dipersiapkan Sumber Daya Manusia yang menguasai Teknologi Informasi;

3) Perlu pembagian tugas yang jelas guna mengoptimalkan pekerjaan dengan lebih menekankan pada pola pendekatan psikologi personel dan sosiologis budaya.

4) Perlunya dukungan fasiltas bagi staf atau pelaksana dalam upaya mengoptimalkan kinerjanya.

c. Disposisi/Sikap Pelaksana:

1) Perlu dibangunnya persepsi yang utuh dan sama bagi Aparat Pelaksana sebagai Pengelola Dana Desa;

2) Perlu menciptakan respons yang positif pada Aparat Pelaksana Kegiatan agar dapat bekerja dengan lebih optimal;

3) Perlu diberikan motivasi pada Pelaksana untuk berani bersikap dan menciptakan inovasi dalam bekerja.

d. Struktur Birokrasi:

1) Perlunya penataan tugas dan pembenahan personel bagi Aparat Kampung;

2) Perlunya pendelegasian wewenang melalui Pembagian Tugas bagi Aparat Kampung sesuai Tugas Pokok dan Fungsinya;

3) Perlu dibangunnya koordinasi kerja (internal/eksternal) dengan tetap membangun pola kerja yang humanis dalam pendekatan psikologi personel dan sosiologis budaya. 


\section{DAFTAR PUSTAKA}

Agustino, 2018 Implementasi Kebijakan Publik Model Van Meter dan Van Horn,http// kertyawitaradya.wordpress ss, diakses 5 November 2018, .

Agustino, 2010 Implementasi Kebijakan Publik Model Van Meter dan Van Horn, Rajawali Press, Jakarta..

Akib, Haedar dan Antonius Tarigan, 2008 "Artikulasi Konsep Implementasi Kebijakan: Perspektif, Model dan Kriteria Pengukurannya," Jurnal Baca, Volume 1 Agustus 2008, Universitas Pepabri Makassar.

Arif, Muhammad. 2007. Tata Cara Pengelolaan Keuangan Desa dan Pengelolaan Kekayaan Desa. Pekanbaru: ReD Post Press.

Arikunto, Suharsimi. 2006. Metode Penelitian Kualitatif. Jakarta: Bumi Aksara

Arikunto, Suharsimi. 2010. Prosedur Penelitian. Jakarta: Rineka Cipta

Arikunto, Suharsimi, 1993, Manajemen Penelitian, Jakarta, PT Raja Grafindo, Persada

Bintaro R, 1989 Dalam Interaksi Desa - Kota dan Permasalahannya. Jakarta: Ghalia Indonesia.

Bungin, Burhan. 2009. Penelitian Kualitatif. Jakarta : Kencana

Dunn, William N. 2003. Pengantar Analisis Kebijakan Publik. Edisi Kedua Terjemahnya Samodra Wibawa, Diah Asitadani, Agus Heruanto Hadna, dan Erwan Agus,

Eddy, 1981, Dasar-Dasar Organisasi dan Manajemen. Jakarta: Ghalia Indonesia,

Edward III, George C (edited), 1990 Public Policy Implementing, Jai Press Inc, LondonEngland. Goggin, Malcolm L et al.

Elsye Rosmery,. 2013, Desentralisasi Fiskal. Alqaprint Jatinangor

Fattah, Nanang, 2008, Landasan Manajemen Pendidikan, Bandung: Remaja Rosdakarya, Cet 9
Fransisca Winarni dan Pandhu Yuanjaya, 2016, Implementasi Kebijakan Dana Desa dalam meningkatkan Pembangunan di Desa Wukirsari, Kabupaten Sleman. Jurnal Kajian Ilmu Administrasi Negara, Natapraja Volume 4 No. 1, file: ///C: / Users /TOSHIBA/Downloads /12614 30637-1-SM.pdf, Hal 49-64, diakses tanggal 08 November 2018

Hamidi, 2004, Metode Penelitian Kualitatif, Aplikasi Praktis, Pembuatan Proposal dan Laporan Penelitian, Malang, UMM Press.

Hariyanto, 2000. Belajar dan Pembelajaran sebuah Teori dan Konsep Dasar, PT Remaja Rosdakarya, Bandung.

Harsoyo. 1977. Pengertian Pengelolaan. http: // id.shvoong.com/writing-and speaking/ presenting/2108155-pengertian pengelolaan/. Diakses pada tanggal 18 November 2018,

Henry, Nicholas. 1988. Administrasi Negara dan Masalah-masalah Kenegaraan. Terjemahan: Luciana D. Lontoh. Jakarta: Rajawali.

Huntington, Samuel P. Dan Joan Nelson. 1994. Partisipasi Politik di Negara Berkembang Terjemahnya Sahat Simamora. Jakarta: Rineka Cipta

Husaini Usman, 2006 Manajemen, Teori, Praktik dan Riset Pendidikan, Bumi Aksara, Jakarta.

Irawan, Prasetya. 2007. Penelitian Kualitatif dan kuantitatif untuk ilmu-ilmu sosial. Jakarta: DIA FISIP UI.

Kansil CST dan Christine ST Kansil, 2005. Sistem Pemerintahan Indonesia, Jakarta, Bumi Aksara,

Khuswatun Chasanah, Slamet Rosyadi, Denok Kurniasih, 2017, Implementasi Kebijakan Dana Desa dalam Meningkatkan Pembangunan di Desa Wukirsari, Kabupaten Sleman, IJPA-The Indonesian Journal of Public Administration, Volume 3 No. 2, Desember 2017, diakes tanggal 08 November 2018.

Mardiasmo.2004. Otonomi dan Manajemen Keuangan Daerah. Yogyakarta: Andi. 
Marselina Ara Lili, 2018, Tesis, Pengelolaan Alokasi Dana Desa dalam Upaya Meningkatkan Pembangunan Ekonomi Masyarakat di Desa Magmagan Karya Kecamatan Lumar.

Mazmanian, Daniel A and Paul A. Sabatier. 1983 Implementation and Public Policy, Scott Foresman and Company, USA.

Merilee S. Grindle (dalam Budi Winarno). 2002. Teori dan Proses Kebijakan Publik, Media Pressindo Yogyakarta.

Nanang Fattah, 2008, Landasan Manajemen Pendidikan, Remaja Rosdakarya, Bandung.

Nazir, Moh. 2013. Metode Penelitian. Bogor: Ghalia Indonesia.

Nasution. 2011. Metode Research Penelitian Ilmiah. Jakarta: PT Bumi Aksara.

Ndapa, Adriana Ida, 2015, Tesis: Implementasi Kebijakan Alokasi Dana Desa, dalam Meningkatkan Penyelenggaraan Pemerintahan Desa (Studi Kasus di Wilayah Kecamatan Kanatang, Kabupaten Sumba Timur, Program Pascasarjana, Universitas Terbuka.

Nugroho. Riant, 2009. Public Policy. Jakarta: PT Elek Media Komputindo

Nugroho, R. 2003. Kebijakan Publik: Formulasi, Implementasi dan Evaluasi. PT Elex Komputindo Kelompok Gramedia. Jakarta

Purwanto dan Sulistyastuti, 1991 Analisis Kebijakan dari Formulasi ke Implementasi Kebijakan, Bumi Aksara Jakarta.

Qalyubi, Syihabuddin dkk. 2007. Dasar-Dasar Ilmu Perpustakaan dan Informasi. Yogyakarta: Jurusan Ilmu Perpustakaan dan Informasi Universitas Fakultas Adab UIN Sunan Kalijaga Yogyakarta

Riduwan. 2004. Metode Riset. Jakarta: Rineka Cipta.

Ripley, Rendal B. and Grace A. Franklin, 1986 Policy Implementation and Bureaucracy, Second Edition, the Dorsey Press, Chicago-Illionis.

Sabatier, Paul, 1986 "Top Down and Bottom up Approaches to Implementation Research" Journal of Public Policy 6, 1986.
Sadu Wasistiono dan Simangunsong, Fernandes, Metodologi Ilmu Pemerintahan (Edisi Revisi yang diperluas), 2015, IPDN Press

Simanjuntak, RobertA.1985. Reformasi Hubungan Keuangan Pusat-Dearah, Makalah dalam Seminar Sehari, Kerja Sama LPEM FEUI, ISEI,YBBAKM, 18 Mei, Jakarta

Sudiyono dan Harpowo. 2003. Komunikasi dan Penyuluhan Pertanian. Malang: Banyumedia Publishing, UMM Press,

Sugiyono.2012. Metode Penelitian Kualitatif. Bandung: CV Alfabeta

Sugiyono. 2013. Metode Penelitian Kombinasi. Bandung. CV Alfabeta.

Suharsaputra, Uhar, 2012, Metode Penelitian Kuantitatif, Kualitatif, dan Tindakan,, Refika Aditama

Swanson, B. E. and J.B. Claar, 1984, "The History and Development of Agricultural Extension" in B.E. Swanson (ed), Agricultural Extension, A Reference Manual,

Tabrani A. Rusyan, dkk 1989 Pendekatan dalam Proses Belajar Mengajar. Bandung, PT Remaja Rosdakarya, Bandung.

Tresiana, Novita,.2013. Metode Penelitian Kualitatif. Bandarlampung: Lembaga Penelitian Universitas Lampung.

Wahab, Solichin A 2004. Analisis Kebijaksanaan dari Formulasi ke Implementasi Kebijaksanaan Negara, Jakarta: Bumi Aksara.

Wardoyo.(1980).Kamus Besar Bahasa Indonesia. Jakarta: Balai Pustaka,

Wibawa, Samodra.1994. Evaluasi Kebijakan Publik. Jakarta: PT Raja Grafindo Persada

Widjaja, HAW. 2003. Otonomi Desa "Merupakan Otonomi yang Asli, Bulat dan Utuh. Jakarta: PT Raja Grafindo Persada.

Widodo, Joko, 2001, Good Governance, Sidorajo, Penerbit Insan Cendekia,

Winardi, J 2000. Motivasi \& Permotivasion dalam Manajemen. Jakarta: Raja Grafindo

Wisakti, Daru, 2008, Tesis: Implementasi Kebijakan Alokasi Dana Desa di Wilayah Kecamatan Geyer, Kabupaten Grobogan, Program Pascasarjana Universitas Diponegoro. 


\section{Peraturan Perundang-Undangan}

Undang-Undang No. 6 Tahun 2014 tentang Desa.

Undang-Undang No. 23 Tahun 2014 tentang Pemerintah Daerah,

Peraturan Menteri Dalam Negeri No. 4 Tahun 2007 tentang Pedoman Pengelolaan Kekayaan Desa

Peraturan Pemerintah No. 43 Tahun 2014 dan Peraturan Pemerintah No. 47 Tahun 2015 tentang Pedoman Pelaksanaan Undang-Undang No. 6 Tahun 2014.

Peraturan Pemerintah No. 60 Tahun 2014 tentang Dana Desa yang bersumber dari Anggaran Pendapatan dan Belanja Negara

Peraturan Pemerintah No. 22 Tahun 2015 tentang Perubahan Atas Peraturan Pemerintah No. 60 Tahun 21014 tentang Dana Desa yang bersumber dari Anggaran Pendapatan dan Belanja Negara

Peraturan Menteri Keuangan No. 93/ PMK.07/2015 tentang Tata Cara Pengalokasian, Penyaluran, Penggunaan, Pemantauan, dan Evaluasi Dana Desa.

Permendagri No. 39 Tahun 2015 tentang Kode dan Data Wilayah Administrasi Pemerintah.

Peraturan Menteri Dalam Negeri No. 113 Tahun 2014 tentang Pengelolaan Keuangan Desa.

Permenkeu No. 93/PMK.07/2015 tentang Tata Cara Pengalokasian, Penyaluran, Penggunaan, Pemantauan, dan Evaluasi Dana Desa.

Peraturan Menteri Desa, Pembangunan Daerah Tertinggal, dan Transmigrasi No. 19
Tahun 2017 tentang Penetapan Prioritas Penggunaan Dana Desa Tahun 2018

Peraturan Bupati Mimika No. 11 Tahun 2018 tentang Tata Cara Pembagian dan Penetapan Rincian Dana Desa Setiap Desa Kabupaten Mimika Tahun Anggaran 2018

\section{Internet}

http: //desabangsa. wordpress .com/2015 /02/12/(mengawal-dana desa) diakses Senin, 05 November 2018 Pukul 21.30 WIB)

http: //databoks.katadata.co.id/ datapublish/2018/03/14/apbn-2018pemerintah-alokasikan-dana-desa-rp60-triliun, diakses tanggal 06 November 2018, jam 02.26 WIB

http: /databoks.katadata.co.id/ datapublish/2008/03/14/apbn-2018pemerintah-alokasikan-dana-rp-60triliun, diakses tanggal 06 November 2018, jam 02.34 WIB

http: //www.kemenkeu.go.id/apbn2018 diakses tanggal 28 November 2018, jam 05.35 WIB.

http: //databoks.katadata.co.id/ datapublish/2018/03/14/apbn-2018pemerintah-alokasikan-dana-desa-rp60-triliun, diakses tanggal 06 November 2018, jam 02.34 WIT 